\author{
Tefsir Araştırmaları Dergisi \\ The Journal of Tafsir Studies \\ مجلة تادر للدبدوث التفسديرية \\ www.dergipark.org.tr/tader
}

\title{
Ölülere Dua ve İstiğfar Niyetiyle Kur’an Okuma Meselesi*
}

\author{
Mustafa ÖZTÜRK*
}

\begin{abstract}
$\ddot{O} z$
Bu makale ölülere dua, af ve mağfiret talebiyle Kur’an okunmasının caiz olup olmadığına dair iki farklı görüşü delilleriyle birlikte sunmayı ve sonuç kısmında bu görüşlerden hangisinin daha sağlıklı olduğuna dair bir kanaat belirtmeyi amaçlamaktadır. Kur'an'ın dua niyetiyle okunması ve bilhassa ölülerin ardından Kur'an okunup sevabının bağışlanması gibi konular İslam geleneğinde erken dönemlerden itibaren tartışılmışır. Gelenekte âlimlerin büyük çoğunluğu bu konuda olumlu görüş bildirirken, diğer bazı âlimler özellikle "İnsan ancak kendi çabasının karşılığını görür" mealindeki Necm 53/39. ayeti delil göstererek Kur'an okuyup sevabını ölülere bağı̧̧lamanın caiz/meşru olmadığını savunmuştur. Klasik kaynaklarda mesele daha ziyade "Hayattaki insanların ibadet mahiyetindeki amellerinden ölülerin ruhları istifade eder mi etmez mi?" şeklindeki bir soru etrafinda tartışılmıştır.

Son dönem İslam dünyasında dua niyetiyle Kur'an okumaya karşı olumsuz görüş daha ziyade Selefî ve Vehhâbî çevrelerce dile getirilir. Özellikle modern zamanlarda hayli rağbet gören bu görüşün aksine Türkİslam kültüründe hemen her vesilesiyle özellikle Fâtiha okunması da çok yaygin bir gelenektir. Mezar taşlarındaki "Ruhuna el-Fâtiha" ifadesi bu geleneğin belki de en meşhur görsel simgesidir. "Ruhuna el-Fâtiha" geleneğinin hem Fâtiha suresinin genel mana ve muhteva açısından Kur'an'ın özü/özeti olmasıyla hem de bu surenin dua/niyaz olarak okunmasıyla irtibatlı olduğu söylenebilir. Çağdaş Vehhâbî ve Selefî çevrelere ait dinî literatürde duanın akabinde veya ölülerin ruhlarına bağışlamak üzere Fâtiha okumanın bidat olduğu açıkça belirtilir. Hatta "bidat" bu çerçevede büyük bir masiyet olarak değerlendirilir. Bu görüş kimi zaman İbn Teymiyye'nin (ö. 728/1328) çeşitli eserlerinden yapılan alıntılarla desteklenir. İbn Teymiyye'nin bidat konusunda çok hassas olduğu bilinmektedir. Bu bakımdan onun ve takipçilerinin meyyite Kur'an okumanın caiz olup olmadığı hususunda ne düşündükleri önemlidir. Ayrıca İbn Teymiyye'nin bu konu hakkındaki görüşlerinin tam manasıyla ortaya konulması özellikle çağdaş Selefî çevrelerde onun görüşlerinin sağlıklı şekilde aktarllıp aktarılmadığı veya bu konuda herhangi bir dezenformasyon yapılıp yapılmadığı gibi konuların da açılığa kavuşmasına imkân verecektir.
\end{abstract}

Anahtar Kelimeler: Kur'an Okuma, Dua, İstiğfar, Sevap, Salih Amel

* Bu makale daha önce Karar Gazetesinde aynı adla yayınlanan makalenin geliştirilmiş halidir.

* Prof. Dr., Marmara Üniversitesi İlahiyat Fakültesi Tefsir Ana Bilim Dalı. mustafaozturk65@outlook.com. ORCID: https://orcid.org/0000-0002-7496-4385.

Bu makale "iThenticate" intihal tarama programında taranmış ve intihal içermediği tespit edilmiştir.

ATIF: Öztürk, Mustafa. "Ölülere Dua ve İstiğfar Niyetiyle Kur'an Okuma Meselesi”. Tefsir Araştırmaları Dergisi 3 / 1 (Nisan 2019): 85-106.

Gönderim Tarihi: 19 Şubat 2019. Kabul Tarihi: 15 Nisan 2019. DOI NUMARASI: 10.31121/tader.529194.

Araştırma Makalesi Yayın Tarihi: 30 Nisan 2019. 


\title{
The Subject of Reciting Qur'an for the Dead on the Purpose of Praying and Absolution
}

\begin{abstract}
This essay aims to present two different points of view with regard to permissibleness of reciting Qur'an for the dead, through their own testimonials. The subjects of reciting Qur'an as a praying and bestowing the good deed yielded from it for the spirit of the dead have always been a topic of debate within Islamic tradition as of the early times. Most of the scholars in Islamic tradition are known to have found it favourable while the others have disapproved recitation of the Qur'an and then bestowing the good deed for the dead, deducing from the verse 53 an-Najm: 39 telling "And that there is not for man except that (good) for which he strives". In classical scholarship, the debate topic seems to have revolved around the question "whether spirits of the dead could avail from the good deeds of the alive, or not".

In recent Islamic world, the opposing point of view targeting recitation of the Qur'an as a prayer is being voiced particularly by Salafi and Wahhabi circles. In contrast with this approach, which is highly popular especially in the modern times, it is a rather widespread custom in Turkish-Islamic tradition to recite Qur'an and al-Fatihah in particular on every occasion. It is fair to say that the epitaph "al-Fatihah for the spirit of the dead" on tombstones is the most well-known symbol of it visually. It can be said that al-Fatihah's bearing quality of being an abstract and a core of the Qur'an in terms of its meaning and content together with its functionality as a prayer and suppliance for God have been prevailing for nascence of the custom of "alFatihah for the spirit of the dead". Within theological scholarship of modern Wahhabi and Salafi groups, it is clearly recorded that recitation of al-Fatihah succeding the prayer or bestowing it for the spirit of the dead are both innovations "bid'ah" in religion and the innovation in religion is cathegorized as exorbitance. This idea is occasionally grounded by references to miscellaneous works by ibn Taymiyyah (d.728/1328). Ibn Taymiyyah is known to be rather discreet with regard to the innovation in religion. So, Ibn Taymiyyah and his successors' approaches relevant to recitation of the Qur'an for the dead are highly significant. Likewise, ascertaining Ibn Tymiyyah's views of this matter in full measure can shed light for the other cases comprising of whether his successors are trasferring his own views in a reliable matter or not, and any disinformation that is possible to exist.
\end{abstract}

Keywords: Recitation of Qur'an, Prayer, Absolution, Good Deed, Good Act.

\section{GİRIŞ}

Gerek dua ve niyaz gerekse ahirete irtihal etmiş müminler için Allah’tan af/mağfiret istirhamında bulunmak ve sevap bağışlamak gibi niyetlerle Kur'an okunmasının meşru olup olmadığ1, İslam geleneğinde öteden beri tartış1lan bir konudur. Bu meselenin günümüz Türkiye'sinde de zaman zaman tartışmaya açıldığı bilinen bir husustur. Bilhassa ölünün ardından dua maksadıyla Kur'an okuma meselesinin yanında namazda teşehhüd ve tahiyyât duası okumanın meşruiyetini tartışmaya açmak, Kur'an'ın tercümesiyle namaz kılmanın ve namazda okunacak surelerin/ayetlerin Türkçe anlamlarını bilerek okumanın bu ibadetin ruhuna daha uygun olduğunu savunmak gibi fikirler sosyal medya mecralarında da sık sık dolaşıma sokulmaktadır.

Bu makalede bilhassa ölülerin ardından sevap bağışlama niyetiyle Kur’an okunmasının meşru olup olmadığı meselesi farklı görüşler açısından ele alınıp değerlendirilecek ve ilgili görüşlere ait deliller/gerekçeler objektif bir yaklaşımla serdedilecek, sonuç kısmında ise söz konusu görüşleri de dikkate alan bir kanaat belirtilecektir. Başka bir ifadeyle, bu çalışma, Kur'an'ın dua ve sevap niyetiyle 
okunmasının temel dinî kaynaklar ve referanslar açısından meşru olup olmadığı meselesini ele almayı ve klasik dinî literatürdeki farklı anlayışları göz önünde tutarak tartışmayı amaçlamaktadır. Ancak bu tartışmada, iki farklı görüşten birini en başından sahiplenip karşıt görüşü değersizleştirmek gibi bir peşin hükme tabi olunmayacak, bilakis anlayıcı bir yaklaşımla her iki görüşün de delilleri/gerekçeleri ortaya konulup sağlıklı bir sonuca ulaşma hedefi ön planda tutulacaktır.

\section{Dua ve Sevap Niyetiyle Kur'an Okumayı Reddeden Anlayış}

İçinde bulunduğumuz modern zamanlarda dinî alanla ilgili birçok konuda geleneksel kabullere çoğunlukla olumsuz bakan anlayışın dua ve sevap niyetiyle Kur'an okunması hususunda çok sık öne sürdüğü itiraz gerekçelerinden biri, “Kur'an dua/niyaz niyetiyle okunup ölülerin ruhlarına sevap bağışlanması gibi maksatlarla nazil olmuş bir kelam değildir” şeklinde formüle edilebilir. Bu anlayışa göre Kur'an'ın indiriliş amacı, Bakara 2/2, 185 ve Âl-i İmrân 3/4, 23 gibi birçok ayette bildirildiği üzere başta müminler olmak üzere tüm insanlara rehberlik etmek, yol göstermektir. Kur’an’ın ölülere değil, dirilere okunması gerektiği yönündeki görüş ve anlayışın kimi zaman vecize gibi dillendirdiği gerekçelerden biri de Yâsîn 36/70. ayetteki “" (Diri olanları uyarmas1 için...) ifadesidir. ${ }^{1}$

Burada bir ara söz olarak Yâsîn 36/70. ayetle ilgili bu istidlal tarzına dair kısa bir değerlendirmede bulunmak gerekirse, bize göre ölülerin ardından dua, istiğfar ve Allah’tan af ve mağfiret istirhamı niyetiyle Kur'an okunmasının caiz olmadığı iddiasını bu ayet üzerinden gerekçelendirmek Kur'an'ın kavram ve anlam dünyasına yabancı olmanın bir göstergesidir. Çünkü Kur’an'daki birçok ayette "iman" kavramı nur/aydınlık, hayat ve canlılık, "şirk" ve "küfür" kavramları ise zulmet/karanlık diye sembolize edilir. Benzer şekilde çeşitli ayetlerde de müminler “ahyầ' (diriler), kafirler ve

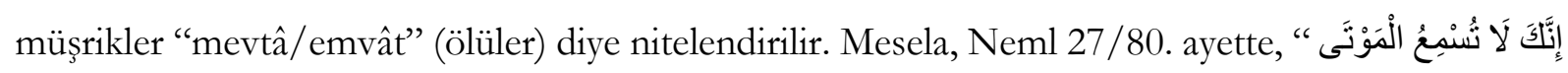

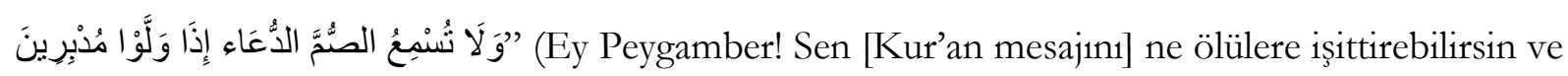

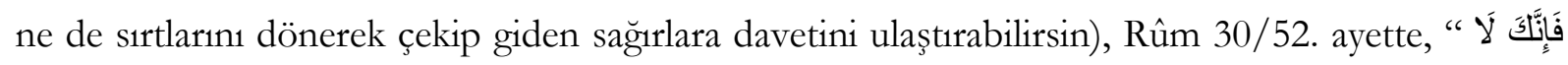

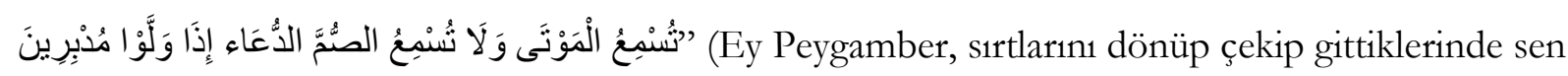

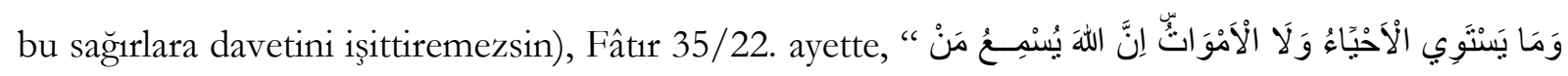

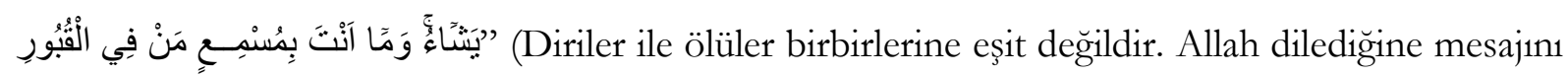
işittirir; oysa sen kabirlerdeki kimselere işittiremezsin) denilir.

Bu ayetler dikkate alındığında, “ölü” ve "ölülük” tabirlerinin istiare yoluyla hak ve hakikati idrak yetisi körelmişlik ve kâfirlikte dirençlilik hâlini belirttiği rahatlıkla anlaşılabilir. Dolayısıyla

1 Bk. Ramazan Yelken, “İnananlar İçin Hâlâ Vakit Gelmedi mị?”, Kalem Dergisi 1 (Ocak-1988): 15. 
Yâsîn 36/70. ayette geçen "hayy" kelimesi de istiare yoluyla "kemâl-i akıl, aklıselim ve sağduyu sahibi kimse” anlamına gelir ve dolayısıyla ilgili ayetteki "مَن كَانَ حَيَّا "(Diri olan kimseler) ifadesi bir teşbîh-i beliğ olarak "idraki canlı ve zinde kimse" gibi bir anlam içerir. Bu ifadedeki maksat, Kur'an'ın ortaya koyduğu deliller karşısında tıpkı ölü gibi hiçbir tepki vermeyip tamamen duyarsız

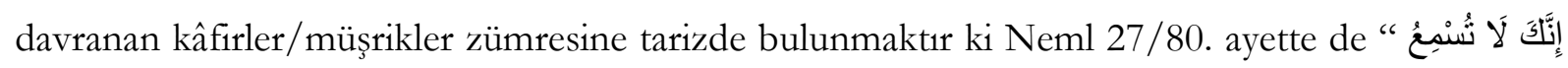

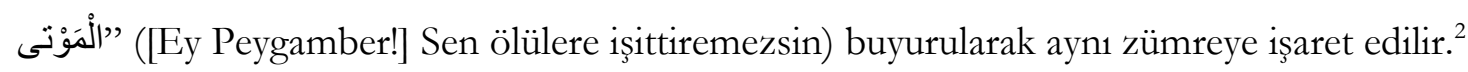

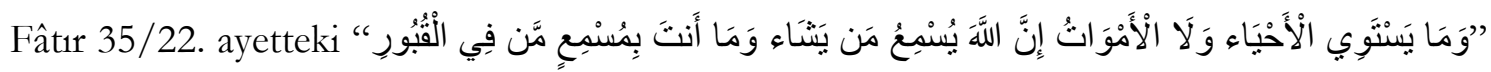
ifadesine gelince, İbn Kuteybe (ö. 276/889), “Bu ayette sözü edilen dirilerden maksat akıl ve idrak sahipleri, ölülerden maksat cahillerdir” demiştir. Tâbî müfessir Katâde’ye (ö. 117/735) göre söz

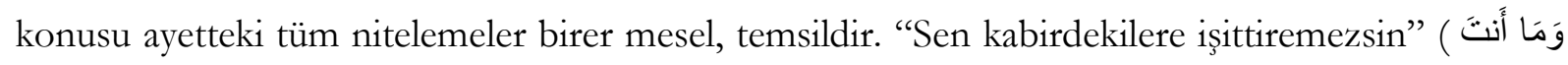
mealindeki ifade ise, “Sen küfür ve şirkin kalplerini öldürdüğü kimselere hak ve hakikat adına hiçbir şey işittiremezsin, yani sen ölmüş kimselere işittiremeyeceğin gibi kalpleri ölmüş kimselere de tebliğini işittiremezsin" demektir. ${ }^{3}$

Kısacas1, Yâsin 36/70. ayet, dua ve mağfiret istirhamında bulunmak niyetiyle ölülerin ardından Kur'an okunup okunmaması meselesiyle ilgili değildir. Kaldı ki birçok hadis kaynağında, her

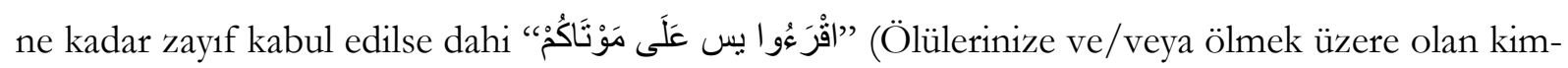
selerinize Yâsîn okuyun" mealinde bir rivayet nakledilir. ${ }^{4}$ Bu rivayet hem sübut hem delalet yönünden ihtilaflı kabul edilebilir. Mamafih, ölülerin ardından Kur'an okunmasının caiz olmadığına yönelik görüşün delil gösterildiği surenin İslâmî kaynaklarda bu görüşün aksine bir rivayete konu olması ironiktir.

Modern dönem İslam dünyasında dua niyetiyle Kur'an okumaya karşı olumsuz görüş daha ziyade Selefî ve Vehhâbî çevrelerce dile getirilir. Bilhassa modern zamanlarda hayli rağbet gören bu görüşün aksine Türk-İslam kültüründe hemen her vesilesiyle özellikle Fâtiha okunması da çok yaygın bir gelenektir. Mezar taşlarındaki "Ruhuna el-Fâtiha" ifadesi bu geleneğin belki de en meşhur görsel simgesidir. "Ruhuna el-Fâtiha" geleneğinin hem Fâtiha suresinin genel mana ve muhteva açısından Kur'an'ın özü/özeti olmasıyla hem de bu surenin dua/niyaz olarak okunmasıyla irtibatlı

Muhammed Tâhir İbn Âşûr, Tefsîru't-Tahrîr ve’t-Tenvîr, (Tunus: Dâru’t-Tûnîsiyye, 1984), 23: 66.

Ebû Abdillah Muhammed b. Ahmed el-Kurtubî, el-Câmi' li Abkâmi'l-Kur'ân, nşr. Ahmed Berdûnî̀ibrahim Itfeyyiş, (Kahire: Dâru'l-Kütübi'l-Kütübi'l-Misriyye, 1964), 14: 340. Ayrıca bkz. Ebû Ca'fer Muhammed b. Cerîr et-Taberî, Câmiu'l-Beyân fî Te'vîli Âyi'l-Kur'ân, nşr. Ahmed Muhammed Şâkir, (Beyrut: Müessesetü'r-Risâle, 2000), 20: 458-459.

4 Ebû Dâvûd Süleymân b. Dâvûd et-Tayâlisî, el-Müsned, nşr. Muhammed b. Abdilmuhsin et-Türkî,, (Kahire: Dâru Hecr, 1999), 2: 244. 
olduğu söylenebilir. Bu bağlamda, "Zikrin en üstünü lâ ilâhe illallah demek, duanın en yücesi elhamdülillah demektir" ${ }^{25}$ mealindeki hadis de konuyla irtibatlandırılabilir.

Öte yandan, hemen her vesileyle Fâtiha okuma geleneğinin özellikle halk arasında çok yaygin olmasında tasavvuf ve tarikat kültürünün önemli rol oynadığından da söz edilebilir. Zira Türk-İslam kültüründeki folklorik din anlayışının büyük ölçüde tarikat ve tekke etrafinda şekillendiği bilinmektedir. Dolayısıyla bazı tarikatların evrad ve ezkârında Fâtiha'nın özel bir önemi haiz olması bu surenin çok çeşitli vesilelerle okunmasına yol açmıştır, denilebilir. ${ }^{6}$ Daha açıkçası, Türkiye sathında Nakşibendiyye tarikatının en güçlü temsilcisi konumundaki Hâlidiyye kolunda Hatm-i Hâcegân zikri çok özel bir yere sahiptir ve bu zikirdeki en önemli unsur Fâtiha suresidir. Hatm-i Hâcegân zikrinin başında ve sonunda yedi kez Fâtiha suresi okunur. Yedi kez okuma surenin ayet sayısıyla alakalıdır. Zikrin hem başında hem sonunda okunması ise Fâtiha suresinin genel mana ve mefhum itibariyle Kur'an'ın hem özü/özeti olarak değerlendirilmesi hem de baştan sona hatim gibi telakki edilmesiyle irtibatlı olmalıdır.

Bu mesele bir tarafa, Mısır ve Suudi Arabistan gibi ülkelerdeki birçok dinî müesseseye ait güncel fetva metinlerinden edindiğimiz kanaate göre gerek Allah'tan af ve mağfiret istirhamıyla gerek vird ve tesbihat maksadıyla Fâtiha okuma geleneği büyük ölçüde Türk-İslam kültürüne mahsus bir uygulama gibidir. Burada “Türk-İslam kültürü” tabirini İslam dininin kendisine veya özüne ilişkin bir normatif değerlendirme olarak değil, bu dinin farklı kültürlerdeki algılanış, yorumlanış ve uygulanış biçimiyle ilişkili bir niteleme olarak kullandığımızı özellikle ifade etmek isteriz.

Çağdaş Vehhâbî ve Selefî çevrelere ait dinî literatürde duanın akabinde veya ölülerin ruhlarına bağışlamak üzere Fâtiha okumanın bidat olduğu açıkça belirtilir; hatta bidat bu çerçevede büyük bir masiyet olarak değerlendirilir. ${ }^{7}$ Temel dinî düşüncesi İbn Teymiyye (ö. 728/1328), İbn Kayyim elCevziyye (ö. 751/1350) ve Muhammed b. Abdilvehhâb (ö. 1206/1792) gibi isimlerin etkisi altında gelişen son devir hadis âlimi Nâsıruddîn el-Elbânî’nin (ö. 1999) yaklaşımına göre ölü adına Kur’an okumak meşru değildir. Nitekim bu görüşü savunanlara göre de şayet meşru olsaydı Rasûlullah bunu yapar ve ashabına öğretirdi. Özellikle Hz. Âişe kabirleri ziyaret ettiğinde neler söyleyeceğini sormuş, Hz. Peygamber ona kabirlere nasıl selam verip nasıl dua edeceğini belirtmiş, fakat Fâtiha ya da Kur'an'dan başka herhangi bir bölümü okumasını öğretmemiştir. Şayet ölünün ardından se-

Tirmizî, "Daavât", 9; İbn Mâce, "Edeb”, 55

Mustafa Öztürk, İlâhî Hitâbın Tefsiri, (Ankara: Ankara Okulu Yayınları, 2018), 1: 114-115.

Bk. Sâlih b. Fevzân b. Abdillah el-Fevzân, el-Bid'a Ta'rîfuhâ Envâubâ ve Ahkâmubâ, (Riyad: el-Mektebetü't-Teâvünî li'd-Da’ve ve'l-İrşâd, 1422), 39-41. 
vap bağışlamak niyetiyle Kur'an okumak meşru olsaydı, Hz. Peygamber bunu Hz. Âişe'den gizlemezdi. Kaldı ki Hz. Peygamber'in ihtiyaç duyulduğu zamanda gerekli beyanda bulunmaması usûl ilminde tespit edildiği üzere caiz değildir. Şayet Hz. Peygamber sahabeye ölülerin ardından Kur’an okumak gibi bir şey öğretmiş olsaydı, bu bilgi bize mutlaka nakledilirdi. Sağlam senetle bize bilgi ulaşmaması ölülere Kur’an okuma uygulamasının asılsız olduğunu gösterir. ${ }^{8}$

Bu görüş kimi zaman İbn Teymiyye’nin çeşitli eserlerinden yapılan alıntılarla desteklenir. Bilindiği üzere İbn Teymiyye bidat konusunda çok hassas bir âlimdir. Bu bakımdan onun ve takipçilerinin meyyit için Kur'an okumanın caiz olup olmadığı hususunda ne düşündükleri önemlidir. Ayrıca İbn Teymiyye’nin bu konuya dair görüşlerinin tam manasıyla ortaya konulması bilhassa çağdaş Selefî çevrelerde onun görüşlerinin sağlıklı şekilde aktarılıp aktarılmadığı veya bu konuda herhangi bir dezenformasyon yapılıp yapılmadığı gibi hususların da açıklığa kavuşmasına imkân verecektir.

Türkiye özelinde konuşmak gerekirse Kur'an'ın dua ve sevap maksadıyla okunmasının meşru olmadığı yönündeki görüşün son dönem İslam dünyasında Mısır, Pakistan gibi farklı dinî, siyasi kültürlerin ikliminde yetişen Seyyid Kutub (ö. 1966), Ali Şeriati (1977), Mevdudi (ö. 1979) gibi müslüman ilim ve fikir adamlarına ait kitaplardaki eleştirel ve sorgulayıcı yaklaşımlardan ilham aldığını söylemek mümkündür. 1960’lı ylllardan itibaren çeşitli eserleri Türkçeye çevrilen bu isimler “Türkiye İslamcıllğğ"ndaki belli bir cenaha geleneksel halk dindarllğını eleştirme hususunda büyük cesaret aşılamıştır. 1980'li yılların sonlarında Mealcilik akımı diye anılan, ilerleyen zamanlarda 'Kur'an İslam"'1 diye adlandırılan dinî söyleme de ivme kazandıran eğilim/yönelim ise geleneksel Kur’an algısına karşı çok sert ve provokatif eleştirileriyle ön plana çıkmıştır.

Türkiye'de yaşanan bu gelişmelerin çok daha öncesinde, yani XX. yüzyılın başlarında dinî alanda 1slah/tecdit fikrini savunan Muhammed Abduh (ö. 1905) ve Reşid Rızâ (ö. 1935) gibi isimlerin öncülük ettiği Neo-Selefî hareket de geleneksel Kur'an tasavvuruna sert eleştiriler yöneltmiştir. Mehmed Âkifin (ö. 1936), “İnmemiştir hele Kur’an, bunu hakkıyla bilin ne mezarlıkta okunmak ne de fal bakmak için"10 şeklindeki dizelerini Muhammed Abduh ve Reşid Rızâ referanslı NeoSelefî hareketteki eleştirel yaklaşımın öz ve özet olarak Türkçeye tercümesi babında değerlendirmek mümkündür.

8 Muhammed Nâsıruddîn el-Elbânî, Ahkâmu'l-Cenâiz, (Beyrut: el-Mektebetü'l-İslâmiyye, 1969), 192-193.

9 Geniş bilgi ve değerlendirme için bk. Mustafa Öztürk, Cağdaş İslam Düşüncesinde ve Kur'ancılık, (Ankara: Ankara Okulu Yayınları, 2013), 185-245.

10 Mehmet Akif Ersoy, Safahat, der. Ömer Rıza Doğrul, (İstanbul: İnkılap ve Aka Kitabevi, 1979), 170. 
Bütün bunlara rağmen, yani gerek İslamcllık gerek Mealcilik gibi fikrî akımların tüm eleştirilerine rağmen Türkiye'deki müslüman halk tabir caizse bildiğinden pek şaşmamış; ölülerin ruhlarına Fâtiha okuyup hatim indirmekten türbe ve mezar ziyaretine kadar hemen her vesileyle Kur'an okuma geleneğini korumuştur. Türkiye'deki halk İslam'ı tecrübesinin özellikle bâtıl inançlar konusunda çok problemli bir yapıya sahip olduğu şüphesizdir. Bununla birlikte aynı İslam tecrübesinin hem kutsal değerlere hem dinî ritüeller ve sembollere sayg1 ve sadakat hususunda ilmî ve entelektüel İslam anlayışından daha duyarlı bir yapıya sahip olduğu da tartışma götürmez bir gerçektir. Kabristanda Kur’an okuma geleneğinin caiz olup olmadığı tartışması bir yana, müslüman Türk halkının özellikle kabristanları arife günü ziyaret etmesini insani değerlere sayg1 ve sadakatin bir göstergesi olarak değerlendirmek mümkündür. Bu örf bayramlaşmaya büyükleri ziyaretle başlama hassasiyetinin bir yansıması olsa gerektir.

Geleneksel halk dindarlığı açısından bakıldığında, entelektüel İslamcı çevrelerdeki eleştirel din anlayışı, deyim yerindeyse, kuru bir ideolojik söylem gibi algılanmakta, bu yüzden müslüman halk nezdinde pek umursanmamaktadır. Bu tutum Richard Bevan Braitwaite ve Ludwig Wittgenstein’in dil ve din dilinin işleviyle ilgili görüşlerini hatırlatır. Bir cümlenin anlamını belirleyen ölçütün, onun doğrulanma yöntemi değil, işlevi olduğunu savunan Braithwaite dinî ifadelerin ne deneylerle test edilebilir ampirik iddialar ne de anlamsız saçmalıklar olduğunu düşünür. Ona göre bir ifadede kastedilen bir şey varsa onun bir manası da vardır. Bu düşünce Wittgenstein'ın şu meşhur sözünü hatırlatır: "Anlamını sorma/birak, faydasına bak."11

Wittgenstein'ın bu mottosunda ifadesini bulduğu üzere müslüman Türk halkı da Kur'an okuma kültürü konusunda öteden beri gelenek hâline getirdiği uygulamada ilmî ve müdellel olma ölçütünden ziyade, arka plandaki samimi niyet ve işlevi dikkate almaktadır. Çünkü halk din denince belki her şeyden önce gönül dünyasını mamur kılma ve mutmain olma ihtiyacını karşılayacak bir kutsiyeti anlamaktadır. Buna karşın dinî epistemoloji temelinde halk İslam'ını eleştiren çevreler sahih ve sağlam bilgi ölçütünü ön plana çıkarmaktadır. ${ }^{12}$ Duygu yoğunluğuyla yaşanan dinî tecrübe sıcaktır; bilgi yoğunluğuyla yaşanan dinî tecrübe ise aydınlatıcı olmakla birlikte soğuktur. Belli ki halk için öncelikli olan, aydınlanma değil, ısınma ihtiyacıdır. Sonuçta müslüman halkın İslamcı entelektüel çevrelerdeki bunca eleştiriyi duymazdan gelmesi, dua ve sevap maksadıyla Kur’an okuma-

11 Ali Yıldırım, Din Dilinin Anlamı: Doğrulamacı ve İslevselci Yakelaşımlar, (Doktora Tezi, Marmara Üniversitesi, 2012 ), 71.

12 Bkz. Mustafa Öztürk, "İslâmî Kökenciliğin Bir Tezahürü: Mealcilik”, İslâmiyât 10/1 (2007): 129-130. 
nın meşru olmadığı yönündeki görüşün kimi İslamcı entelektüel çevrelerde hırçın denebilecek biçimde savunulması gibi bir sonuç doğurmuş ve bu durum konunun sağduyulu bir yaklaşımla ele alınmasını zorlaştırmıştır.

\section{Meselenin İslâmî Kaynaklardaki Genel Tartışma Çerçevesi}

Dua ve sevap niyetiyle Kur'an okumanın caiz olup olmadığı, okunsa dahi Kur'an tilavetinden hâsıl olan sevabın ölüye ulaşıp ulaşmayacağı gibi konular İslam'ın erken dönemlerinden itibaren tartışılmıştır. Bir başkasının yerine hac yapma ve oruç tutma türünden meselelerle irtibatlı olarak daha ziyade Muvaffakuddîn İbn Kudâme'nin (ö. 620/1223) el-Muğnîsi gibi fikıh kitapları ve Ebû Zekeriyyâ en-Nevevî'nin (ö. 676/1277) el-Minhâc, el-Mecmû́, el-Ežkâr gibi muhtelif eserleri ile Hatîb et-Tebrîzî̀nin (ö. 741/1340) Mişskâtü'l-Mesâbîh adlı eserine Ali el-Kârî (ö. 1014/1605) tarafindan yazılan şerh gibi kitaplarda ele alınan bu konu İbn Ebi'l-İzz'in (ö. 792/1390) Şerbü'l-Akâidi'tTahâviyye adlı eseri gibi bazı akâid kitaplarının şerhlerinde de kendine yer bulmuştur.

Son dönem Hanefî fakihlerinden İbn Âbidîn (ö. 1252/1836) ölülere Kur'an okuma konusuna da önemli bir yer ayırdığı Şifâu'l-Alîl ve Bellü'l-Ğalîl isimli bir risale kaleme almıştır. Ancak bu konu en geniş şekliyle sistematik Selefiliğin kurucu isimleri konumundaki İbn Teymiyye ile en meşhur talebesi İbn Kayyim el-Cevziyye'ye ait eserlerde ele alınıp tartışılmıştır. Bu durum Selefilliğin protest karakterli bir dinî düşünce tarzı olarak "bidat” konusunda aşırı duyarlılık göstermesiyle alakalı olmalıdır. Nitekim İbn Teymiyye referanslı sistematik Selefiliğin tabir caizse karikatürize edilmişşekli gibi görünen Vehhâbîlik Kur'an'ın dua ve sevap niyetiyle okunmasını bidat olarak tanımlamıştır.

Ebû Zekeriyyâ en-Nevevî duanın ölülere fayda vereceği ve sevabının onlara erişeceği husu-

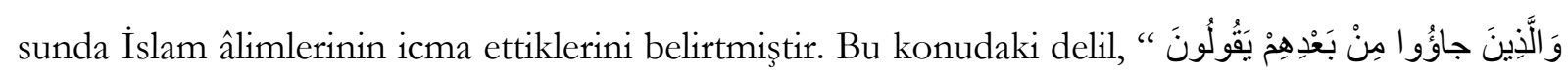

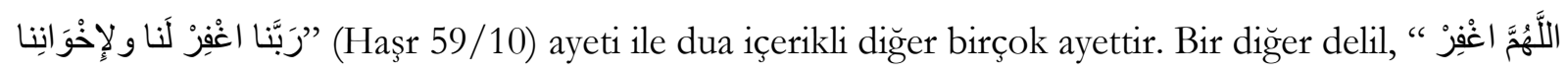
لحينا وميتنا (Allah'ın, hayatta olan(lar)ımızı ve ahirete irtihal etmiş bulunan(lar)ımızı af/mağfiret eyle) ${ }^{13}$ gibi hadislerdir. Kur'an tilavetinden hâsıl olan sevabın ölüye ulaşıp ulaşmadığı konusunda ise ihtilaf edilmiştir. İmam eş-Şâfî̀’nin (ö. 204/820) meşhur görüşü Kur’an tilavetinden ölüye herhangi bir sevap ulaşmayacağ1 yönündedir. Ahmed b. Hanbel ve bir grup âlim ile bazı Şâfiîler ise sevabın ölüye ulaşacağ1 görüşünü benimsemişlerdir. ${ }^{14}$ Hatta Ebû Bekr el-Mervezî (ö. 292/905) İmam Ahmed b. Hanbel'in, "Kabristana girdiğinizde ölülere Fâtiha, Muavvizeteyn ve İhlâs surelerini okuyun. Bu sureleri okumanın sevabı ölülere ulaşır” dediğini işitmiştir. Ebû Ali ez-Za’ferânî (ö. 260/874) de

13 Bkz. Ebû Dâvûd, "Cenâiz", 60; Tirmizî, "Cenâiz", 38; İbn Mâce, "Cenâiz", 23.

14 Ebû Zekeriyyâ Muhyiddîn Yahyâ b. Şeref en-Nevevî, el-Eqkâr, nşr. Abdülkâdir el-Arnaût, (Beyrut: Dâru’l-Fikr, 1994), 164-165; a. mlf., Sabîhu Müslim bi-Şerbi'n-Nevevî (el-Minhac fi șerbi Sabîhi Müslim b. Haccâc), (Beyrut: Dâru İhyâi'tTürâsi'l-Arabî, 1392/1972), 1: 90. 
İmam eş-Şâfî̀'ye “Kabristanda Kur'an okumanın hükmü hakkında sormuş, Şâfî̀ de "Bunda sakınca yok" diye karşıllk vermiştir. ${ }^{15}$

Şâfiî fakih Ebü’l-Hasen el-Mâverdî’nin (ö. 450/1058) aktardığı bilgiye göre Kûfe ehlinden bazıları Necm 53/39. ayeti delil göstererek ölüye hiçbir sevabın ulaşmayacağı görüşünü savunmuşlardır. Bazı kaynaklarda, İzzeddin b. Abdisselâm’ın (ö. 660/1262) da Kur'an tilavetinden hâsıl olan

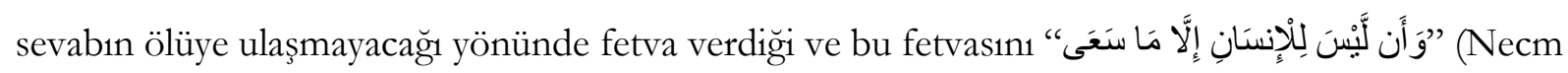
53/39) ayetiyle gerekçelendirdiği belirtilmiştir. ${ }^{16}$ Maverdî, "Kûfe ehli”" derken muhtemelen bazı Hanefî fakihleri kastetmiş olsa gerektir. Zira meşhur Hanefî fakih ve usulcü Ebû Bekr el-Cessas'nn (ö. 370/981) Necm 53/39. ayetle ilgili olarak, "Bu ayette her bir mükellefin fiilleriyle ilgili ahkâmın başkasına değil, sırf kendisine taalluk ettiği, hiçbir mükellefle ilgili olarak bir başkasının tasarrufta bulunmasının caiz olmadığı hususunda delil vardır" ${ }^{\prime 17}$ şeklindeki istidlali Mâverdînnin, "Kûfe ehlinden bazıları" tanımlamasıyla Hanefî fakihleri kastetmiş olma ihtimalini güçlendirir.

Aksi yöndeki görüşü savunan âlimler, “İlk muhacirlerden sonra hicret eden müminler Allah’a şöyle niyaz ederler: "Rabbimiz! Bizi ve bizden önce iman eden din kardeşlerimizi affeyle. Kalplerimizde müminlere karşı kin ve kıskançlık gibi duygulara yer verme. Rabbimiz! Hiç şüphe yok ki sen

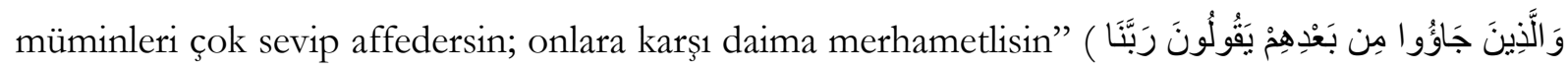

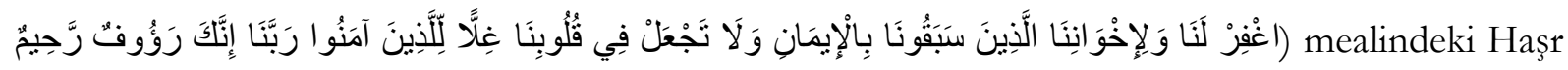
59/10. ayet ile “Allah ve melekleri Peygamber'e salat ederler. Ey Müminler! Siz de ona salât ve

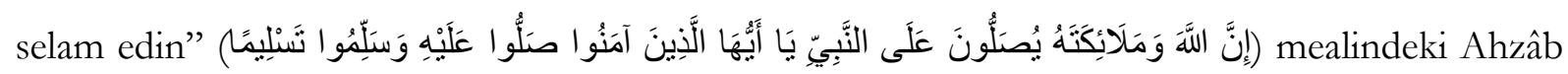
33/56. ayeti delil göstermişlerdir. ${ }^{18}$

Suyûtî (ö. 911/1505) el-îtkân’ da “'̇̇mamımız Şâfiî hariç diğer üç mezhep imamı sevap niyetiyle okunan Kur'an'ın ölülere bağışlandığında bu sevabın yerine ulaşacağ1 görüşünü benimsemiştir.

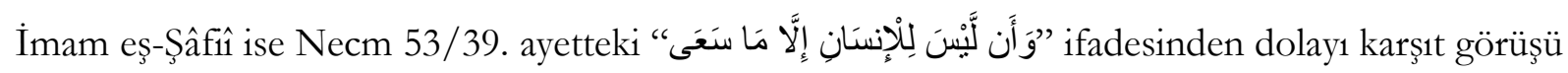

15 Ebü'l-Fazl Şihâbüddîn Ahmed b. Ali İbn Hacer el-Askalânî, el-Imtâ' bi'l-Erbaîne'l-Mütebayineti's-Semâ, nşr. Ebû Abdillah Muhammed Hasen, (Beyrut: Dâru'l-Kütübi'l-İlmiyye, 1997), 85.

16 Ebû Abdillah el-Kurtubî’nin (ö. 671/1273) aktardı̆̆ı ilginç bir rivayete göre İzzeddîn b. Abdisselâm vefat edince, hayatta iken sürekli beraber olduğu dostlarından biri onu rüyasında görmüş ve "Sen hayatta iken ölülere Kur'an okumanın ve sevabını bağışlamanın anlamsız/faydasız olduğunu söylüyordun. Şimdi de aynı görüşte misin?” diye sormuş, İbn Abdisselâm da şöyle karşıllı vermiştir: Evet, ben hayatta iken bu görüşü savunuyordum. Fakat Allah'ın lütuf ve ikramını görünce o görüşümü terk ettim. Ölülere okunan Kur'an'ın sevabı onlara ulaşır”. Ebû Abdillah Muhammed b. Ahmed el-Kurtubî, et-Tęłkira bi Abvâli'l-Mevtâ ve Umûri'l-Âbira, (Riyad: Mektebetu Dâri'l-Minhâc, 1425/2004), 292.

17 Ebû Bekr Ahmed b. Ali el-Cessâs, Ahkâmu'l-Kur'ân, nşr. Muhammed Sâdık Kamhâvî, (Beyrut: Dâru İhyâi't-Türâsi'lArabî, 1412/1992), 1: 653, 2: 279.

18 Ebü'l-Hasen Ali b. Muhammed el-Mâverdî, el-Hâvi'l-Kebîr, nşr. Ali Muhammed Muavvız-Âdil Ahmed Abdülmevcûd, (Beyrut: Dâru'l-Kütübi'l-İlmiyye, 1999), 8: 298-299. 
tercih etmiştir” diyerek Şâfî̀ mezhebinin görüşünü aktarmıştır. ${ }^{19}$ Bu ifade tarzı Suyûtînin kendi mezhebinin görüşünü benimsediğini düşündürse dahi Şerbü's-Sudûr adlı eserinde konuyu ele alış tarzı onun da diğer üç mezhep imamına yakın durduğunu ima etmektedir. ${ }^{20}$

Suyûtî’nin Şerbü's-Sudûr'u, Ali el-Kârî’nin (ö. 1014/1605) Mirkâtü'l-Mefâtî̉’i gibi geç dönemlere ait bazı kaynaklarda Ebû Hüreyre'den nakledilen bir rivayete göre Hz. Peygamber kabristanda Fâtiha, İhlâs, Tekâsür gibi surelerin okunup sevabının ölülere bağışlanabileceğini söylemiştir. ${ }^{21}$ Meşhur sahâbî Abdullah İbn Ömer'den nakledildiğine göre Hz. Peygamber, “Sizden biri vefat ettiğinde, cenazesini fazla bekletmeyin, bir an önce kabrine defnedin. Kabrin baş tarafinda Fâtiha, ayak tarafinda Bakara suresinin son ayetleri okunsun" demiştir. ${ }^{22}$ Merfu olarak nakledilen bu hadisin isnat zincirinde yer alan Yahya b. Abdillah ve Eyyûb b. Nehîk gibi raviler zayıf oldukları gerekçesiyle cerh edilmişlerdir. Ayrıca bu hadis Beyhakî (ö. 458/1066) gibi bazı muhaddislerce mevkuf kabul edilmiştir. ${ }^{23}$ Buna mukabil sahâbî Ebü'l-A’lâ b. Âmir el-Leclâc'in oğluna vasiyetiyle ilgili olarak nakledilen, "Evladım! Öldüğümde beni mezara koy; mezara koyduktan sonra 'bismillâhi ve alâ milleti rasûlillah' de. Ardından üzerime toprak at ve toprağı tesviye et. Daha sonra da başucumda Bakara suresinin ilk ayetleri ile son kısmındaki ayetleri oku. Çünkü ben Rasûlullah'ın böyle söylediğini işittim" mealindeki hadis Nûruddîn el-Heysemî (ö. 807/1405) gibi bazı muhaddisler tarafından "isnat zincirindeki tüm raviler sika" olarak değerlendirilmiştir. ${ }^{24}$

Konuyla ilgili bir diğer rivayet, daha önce de zikri geçen, "Ölülerinize Yâsîn okuyunuz" mealindeki hadistir. ${ }^{25}$ Ma’k1l b. Yesâr'dan merfu olarak nakledilen bu hadisin manasıyla ilgili olarak İbn Hibbân (ö. 354/965), "Rasûlullah bu sözünde ölen kişiye değil, ölmek üzere olan kişiye Yâsîn okunmasını kastetmiştir” şeklinde bir yorum yapmıştır. ${ }^{26}$ Musanniflerin bir kısmı bu hadisi ölmek üzere olan kişiye yapılacak işlemlerle ilgili bab başlıkları

19 Ebü'l-Fazl Celâlüddîn Abdurrahmân b. Ebî Bekr es-Suyûtî, el-İtkân fî Ulumi'l-Kur'ân, nșr. Muhammed Ebü'l-Fazl İbrahim, (Kahire: el-Hey'etü'l-Misriyyetü'l-Âmme li'l-Küttâb, 1974), 1: 386.

20 Ebü'l-Fazl Celâlüddîn Abdurrahmân b. Ebî Bekr es-Suyûtî, Şerbü's-Sudûr bi-Şerhi i Hâli'l-Mevtâ ve'l-Kubûr, nşr. Abdülmecîd Țu'me el-Halebî, (Beyrut: Dâru'l-Ma'rife, 1996), 301-305.

21 Suyûtî, Serbü's-Sudûr, 303; Ebü'l-Hasen Nûrüddîn Ali b. Sultân Ali el-Kârî, Mirkâtü'l-Mefâtîh, (Beyrut: Dâru'l-Fikr, 2002), 3: 1229.

22 Ebü'l-Kâsım Süleymân b. Ahmed et-Taberânî, el-Mu'cemü'l-Kebîr, nşr. Hamdî Abdülmecîd es-Silefî, (Kahire: Mektebetü İbn Teymiyye, ty.), 12: 444; Ebû Bekr Ahmed b. Hüseyn el-Beyhakî, Şuabü'l-Îmân, nşr. Muhammed Saîd Besyûnî Zağlûl, (Beyrut: Dâru'l-Kütübi'l-i̇lmiyye, 2000), 11: 471.

23 Ebû Bekr Ahmed b. el-Hüseyn el-Beyhakî, Şuabü'l-Îmân, nşr. Abdülalî Abdülhamîd, (Riyad: Mektebetü'r-Rüşd, 2003), 6: 471.

24 Ebü'l-Hasen Nûrüddîn Ali b. Ebî Bekr el-Heysemî, Mecmen'z-Zevâid ve Menben'l-Fevâid, nşr. Hüsâmüddîn el-Kudsî, (Kahire: Mektebetü'l-Kudsî, 1994), 3: 44.

25 Tayâlisî, Müsned, 2: 244; Ebû Dâvûd, "Cenâiz", 24; İbn Mâce, "Cenâiz", 4.

26 Ebû Hâtim Muhammed b. Hibbân el-Büstî, es-Sahîh, nşr. Şuayb el-Arnaût, (Beyrut: Müesssesetü’r-Risâle, 1988), 7: 269. 
altında naklederken, diğer bir kısmı istircâ kapsamında kaydetmişlerdir. Mesela, Ebû Dâvûd (ö. 275/889) hadisteki "mevtâ" kelimesinin ölmüş kimseye delalet ettiği kanaatindedir. Hadisin zahirî manası da bu kanaati teyit etmektedir. ${ }^{27}$ Şevkânî (ö. 1250/1834) ise "Hadisteki lafzıı ölmüş kimseyle ilgili olduğu açıktır. Lafzın henüz ölmek üzere olan kimseyle (muhtazar) ilgili olduğunu söylemek

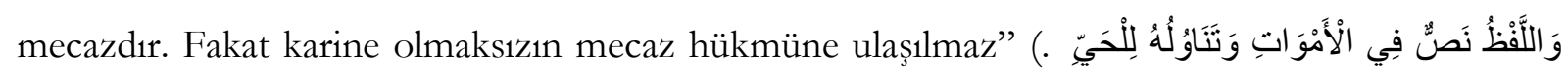
demiştir. ${ }^{28}$

Sonuç olarak, “Ölülerinize Yâsîn okuyun” mealindeki hadis sadece bir sahâbîden nakledilmiş; fakat çeşitli kaynaklarda üç ayrı sahâbîden de söz konusu hadisdeki manayla uyumlu başka haberlere yer verilmiştir. Şahit olarak zikredilen bu üç haber/hadis de zayıf olarak değerlendirilmiştir. Lakin söz konusu haberlerin zayıf olarak değerlendirilmesi mevzu (uydurma) oldukları anlamına gelmez. Bilakis söz konusu haberler ölülere Yâsîn okunması meselesinin bir esasa dayandığına karine teşkil eder. ${ }^{29}$ Öte yandan, Hz. Peygamber'in bir kabristandan geçerken azap çektiklerini söylediği iki ölünün mezarına birer taze hurma dalı dikip, "Belki de bu vesileyle azapları biraz hafifletilir" dediğine dair bir rivayet de sevap niyetiyle okunan Kur'an'ın ölüye fayda edeceği yönündeki görüşün kıyasa dayalı delilleri arasında gösterilir. ${ }^{30}$

Bütün bunların dışında, Cenaze namazında Fâtiha suresi okunması gerektiğine dair hadisler ölülere dua ve istiğfar babında Kur'an okunacağını gösterir. Talhâ b. Ubeydillah bir cenazede İbn Abbâs'ın arkasında namaz kıldığını, İbn Abbâs'ın Fâtiha suresini okuduğunu ve "Bu sünnettir" dediğini söylemiştir. ${ }^{31}$ Hadisin Buhârî (ö. 256/870) tarafından nakledilen varyantında İbn Abbâs'ın

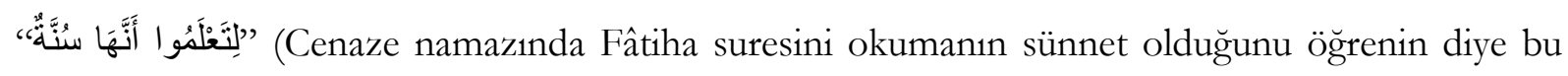
sureyi okudum) kaydına yer verilmiştir. Buhârî şârihi İbn Battâl (ö. 449/1057) cenaze namazında Fâtiha suresini okuma konusunda ihtilaf edildiğini belirtmiştir. Buna göre İbn Mes'ûd, İbnü’z-Zübeyr, İbn Abbâs, Osman b. Habîb, Ebû Ümâme b. Sehl, Mekhûl, Hasen el-Basrî, İmam eş-Şâfî̀, Ahmed b. Hanbel gibi isimler Fâtiha suresinin okunması gerektiği görüşünde iken Hz. Ömer, Hz. Ali, Abdullah b. Ömer, Ebû Hüreyre, Atâ b. Ebî Rebah, Tâvûs b. Keysân, Saîd b. el-Müseyyeb, İbn Sîrîn, Saîd b. Cübeyr, Şa’bî, İmam Mâlik, İmam Ebû Hanife ve takipçileri aksi yöndeki görüşü tercih etmişlerdir. Hanefî âlim Tahâvî (ö. 321/933) bu konuyla ilgili olarak, "İhtimal ki cenazede Fâtihâ

\footnotetext{
27 Yusuf Acar, Rivayet İlimleri Açısından Hayattakilerin Yaptığ İbadet ve Kıraatten Ölülerin Faydalanması Meselesi, (İstanbul: A.H.İ Yayıncllık, 2004), 175.

28 Ebû Abdillah Muhammed b. Ali eş-Şevkânî, Neylü'l-Evtâr, (Riyad: Dâru İbni’l-Cevzî, 1427), 7: 235.

29 Acar, Rivayet İlimleri Açısından Hayattakilerin Yaptı̆̆ İbadet ve Kıraatten Ölülerin Faydalanması Meselesi, 178.

30 Kurtubî, el-Câmi', 10: 267; a. mlf., et-Tękira, 276.

31 Tayâlîsî, Müsned, 4: 460; İbn Hibbân, es-Sabîh, 7: 340-341; Ebû Abdillah Muhammed b. Abdillah Hâkim en-Nîsâbûrî, el-Müstedrek ale's-Sabîhayn, nşr. Mustafa Abdülkâdir Atâ, (Beyrut: Dâru'l-Kütübi'l-İlmiyye, 1995), 1: 510.
} 
suresini okuyan sahâbîler tilavet olarak değil, dua olarak okumuşlardır” şeklinde bir görüş beyan etmiştir. $^{32}$

Tâbî âlim Ebû Âmir eş-Şâ’bî (ö. 104/722), "Ensar sahâbîler ölünün yanına geldiklerinde Bakara suresini okurlardı” (كانت الأنصارُ إذا حضروا الميت قرؤو ا عنده سورة البقرة) demiştir. ${ }^{33}$ İbn Hacer (ö. 852/1449) Şa’bî’nin bu sözünü, “Ensâr ölünün yanında Kur’an okumayı müstehap görürdü” diye nakletmiştir. ${ }^{34}$ Buna mukabil İmam Ahmed b. Hanbel’in görüşlerini derleyen Hanbelî fakih Ebû Bekr el-Hallâl (ö. 311/923) yine Şa'bî’den nakille, “Ensar, içlerinden biri öldüğünde o ölünün yanında Kur'an okunup okunmayacağı hususunda ihtilaf ettiler” demiş, bunun ardından ölüye Kur'an okunabileceğine dair bir dizi rivayet nakletmiştir. ${ }^{35}$

Necm 53/39. ayetin Kur'an tilavetinden hâsıl olan sevabın ölülere ulaşmayacağına dair görüşe delil gösterilmesi, karşıt görüşs sahipleri tarafından şu birkaç gerekçeyle çürütülmeye çalışılmıştır: (1)

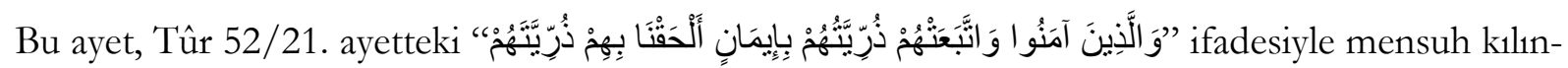
mıştır. Çünkü bu ayete göre Allah, babalarının salih kimseler olmasından dolayı onların çocuklarını ve torunlarını da cennete koymuştur. (2) Necm 53/39. ayet Hz. İbrahim ve Hz. Musa'nın kavimlerine mahsus bir hüküm içerir. Hz. Muhammed’in ümmetine gelince, bu ümmet hem kendi çalışıp çabalamasının sevabına hem de başkalarının kendisi namına yapıp ettiği hayırlı işlerin sevabına nail olur. Bu görüş tâbî müfessir İkrime’ye (ö. 105/723) nispet edilmiştir. (3) Necm 53/39. ayette geçen "el-insân" lafzından maksat "kâfir insan"dır. Mümin hem kendi amelinin hem de kendisi adına yapılan hayırlı amelin sevabına nail olur. (4) Hüseyin b. el-Fadl İbn Umeyr’in (ö. 282/896) yorumuna göre Necm 53/39. ayetteki hüküm, adalet terazisiyle ilgilidir. Fazilet terazisi söz konusu olduğunda Allah dilediği takdirde sevapları arttırır. (5) Necm 53/39. ayette geçen “㳊” (li’l-insân) lafzındaki "lâm" harf-i cerri "alâ" manasındadır. Buna göre "İnsan için kendi yapıp ettiği şeylerden başka bir şey söz konusu değildir”" ifadesi sevaplarla değil, günahlarla ilgili olur. ${ }^{36}$

Suyûtî ve Âli el-Kârî sevap niyetiyle Kur'an okuyup ölülere bağışlama geleneğinin aslında bir başkası adına dua etme, sadaka verme, haccetme, köle azadı gibi amellere kıyas yoluyla gerekçelendirildiğini belirtir. Buna göre nasıl ki bir başkası adına niyabeten hac yapılabiliyorsa, yine bir başkası

32 Ebü'l-Hasen Ali b. Halef İbn Battâl el-Kurtubî, Şerbü Sabîhi’l-Buhârî, nşr. Ebû Temîm Yâsir b. İbrâhîm, (Riyad: Mektebetü'r-Rüşd, 2003), 3: 316-317.

33 Nevevî, el-Ezkâr, 145.

34 Ebü'l-Fazl Şihâbüddîn Ahmed b. Ali İbn Hacer el-Askalânî, Telhîsü'l-Habîr, (Beyrut: Dâru’l-Kütübi'l-İlmiyye, 1989), 2: 246.

35 Ebû Bekr Ahmed b. Muhammed el-Hallâl, el-Kırâe inde'l-Kubûr, nşr. Yahya Murad, (Beyrut: Dâru'l-Kütübi'l-İlmiyye, 2003), 89-90.

36 Ebû Muhammed Bedrüddîn Mahmûd el-Aynî, el-Binâye fî Șerbi'l-Hidâye, (Beyrut: Dâru'l-Kütübi'l-İlmiyye, 2000), 4: 468; Suyûtî, Şerbu's-Sudûr, 302; Ali el-Kârî, Mirkâtü̈l-Mefâtîh, 3: 1229. 
için Kur’an da okunabilir ve sevabı bağışlanabilir. Bu görüşü destekleyen rivayetler tek tek ele alındığında sübut yönünden sahih olmadıkları tespitinde bulunulabilir. Fakat ilgili rivayetlerin toplamından söz konusu geleneğin bir esasa dayandığı sonucu da çıkarılabilir. Bunun içindir ki müslümanlar herhangi bir yadsıma ve yadırgama tavrı söz konusu olmaksızın her dönemde ve her muhitte ölülerine Kur'an okuma geleneğini sürdürmüş ve bu hususta icma oluşmuştur. ${ }^{37}$ İbn Kudâme’ye göre bu görüş Kur'an'daki bazı ayetlerle de desteklenebilir. Konuyla ilişkilendirilmesi mümkün olan

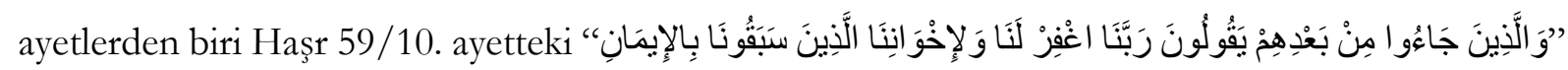

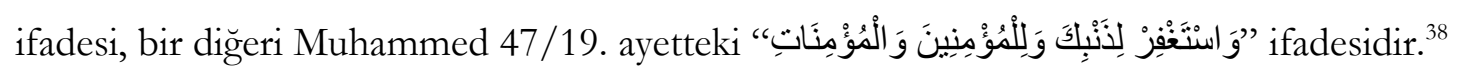

\section{Sistematik Selefî Anlayışın Meseleye Yaklaşım Tarzı}

İslam düşünce tarihinde sistematik Selefiliğin kurucu ismi olarak tanınan İbn Teymiyye, "Büyük fakihler ve öncü âlimler ölüye Kur'an okunması ve bunun sevabının ona ulaşıp ulaşmaması hususunda neler söylemişlerdir?” şeklindeki bir soruya cevap olarak şunları söylemiştir: Selef nezdinde kabirlerin başında daimi olarak Kur'an okumak gibi bir âdetin mevcudiyeti bilinmemektedir. İnsanlar (müslüman âlimler) kabrin başında Kur’an okumanın caiz olup olmadığı hususunda farklı görüşler benimsemişlerdir. Ebû Hanîfe, İmam Mâlik ve bazı rivayetlere göre Ahmed b. Hanbel bunu hoş karşılamamıştır. Ancak İbn Hanbel daha geç tarihli bir rivayete göre kabrin başında Kur'an okumanın caiz olduğu görüşünü benimsemiştir. Bu konudaki görüşünün değişmesi Abdullah b. Ömer'in defin sırasında kendisine Bakara suresinin ilk ayetleri ile son ayetlerinin okunmasını vasiyet ettiği yönündeki haberle ilişkilidir. ${ }^{39}$

İbn Teymiyye, Kur'an okuyup sevabını anne babasına ve uhrevi âleme göçmüş müslümanlara bağışlamanın caiz olup olmadığı hususunda da şunları söylemiştir: Sahih haberlerde bildirildiğine göre Rasûlullah (s.a.v.) ölünün namına sadaka verilmesini ve yine onun için oruç tutulmasını tavsiye etmiştir. Âlimler bu ve benzeri haberlerden hareketle hem mali hem bedeni ibadetlerden hâsıl olan sevapların müslüman ölülere bağışlanabileceğine hükmetmişlerdir ki bu görüş Ahmed b. Hanbel ve Ebû Hanîfe tarafindan da benimsenmiştir. İmam Mâlik ve İmam eş-Şâfî̀’nin taraftarlarından bir kısmı da aynı görüşe iştirak etmiştir.

37 Ebû Muhammed Muvaffakuddîn Abdullah b. Ahmed İbn Kudâme, el-Muğnî, nşr. Abdullah b. Abdilmuhsin etTürkî-Abdülfettâh Muhammed el-Hulv, (Riyad: Dâru Âlemi'l-Kütüb, 1997), 2: 424; Aynî, el-Binâye, 4: 467; Suyûtî, Şerbu's-Sudûr, 302.

38 İbn Kudâme, el-Muğnî, 2: 423.

39 Ebü'l-Abbâs Takıyyüddîn Ahmed b. Abdilhalîm İbn Teymiyye, el-Fetâva'l-Kübrâ, (Beyrut: Dâru'l-Kütübi'l-İlmiyye, 1987), 3: 34; a. mlf., Mecmûu'l-Fetâvâ, nşr. Abdurrahmân b. Muhammed b. Kâsım, (Medine: Mecmeu'l-Melik Fehd, 1995), 24: 140-141, 317.

40 İbn Teymiyye, Mecmûu'l-Fetâvâ, 24: 322, 324. 
(Necm 53/39) ayetini delil göstererek ölülere Kur’an okuyup sevabını bağışlamanın hiçbir anlam ifade etmediğini söylemişlerdir.

İbn Teymiyye bu görüşe şöyle bir gerekçeyle itiraz etmiştir: "Mütevatir sünnet ve icma-i ümmetle sabittir ki ölüye dua ve istiğfarda bulunulur. Bunlar ölüye değil, başkasına ait amellerdir. Yine sahih hadislerle sabit olduğu üzere ölünün namına sadaka verilir. Sadaka ölüye fayda verir ki bu da ölüden başkasına ait bir ameldir. Öte yandan, Allah Necm 53/39. ayette, "İnsana ancak kendi amelleri fayda verir" dememiş, aksine "İnsan ancak kendi yapıp ettikleri şeylere maliktir; bunun dışındaki amellerde hak sahibi değildir” demiştir. Bu sebeple, bir başkası kendi amelini bir insana bağışladığında bu bağış o insana fayda verir. Tıpkı kendisine yönelik duadan ve yine kendisi namına verilen sadakadan faydalanması gibi, ölü kimse gerek akrabasının gerekse başka herhangi bir müslümanın kabir başında ettiği dua ve niyazlardan da nasiplenir. ${ }^{41}$

"İnsan kendi çabasından/amelinden başka hiçbir şeye malik değildir" mealindeki Necm 53/39. ayet ile “Âdemoğlu öldüğünde üç ameli hariç diğer bütün amelleri sonlanır. Bu üç amel sadaka-i câriye (faydası süreklilik arz eden hayırlı iş veya iyilik), faydalı ilim ve kendisine dua edecek

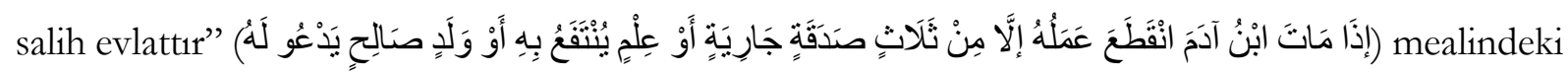
hadis bağlamında, "Bu ayet ve hadis kişi öldüğunde ona hiçbir iyiliğin fayda vermeyeceği anlamına gelir mi?” sorusuna da İbn Teymiyye şöyle cevap vermiştir:

$\mathrm{Bu}$ ayet ve hadis, kişi öldüğünde ona insanların dua ve istiğfarının ve/veya onun namına işlenen iyiliklerin fayda vermeyeceğine delalet etmez. Bilakis İslam'ın büyük ilim önderlerinin ittifakla kabul ettikleri üzere söz konusu ameller ölüye fayda verir. Kaldı ki İslam dininde bunun böyle olduğu 1ztırari/zaruri olarak bilinir ve Kur’an, Sünnet, icma da bunu gösterir. Aksi görüşü savunan-

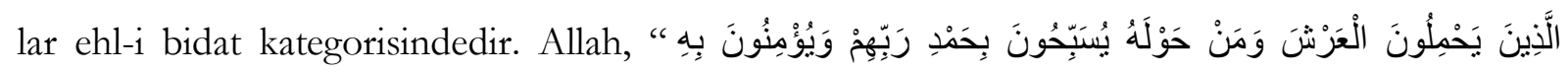

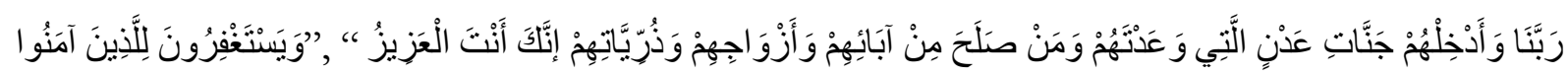

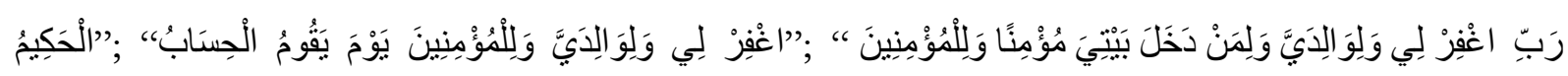
" وَرَالْمُوِْينَاتِ miştir. Bu konuyla ilgili olarak çok sayıda hadis de nakledilmiştir. İbn Abbâs'tan nakledildiğine göre bir adam Rasûlullah'a gelip, "Benim annem vefat etti, onun adına sadaka versem, bu sadaka ona

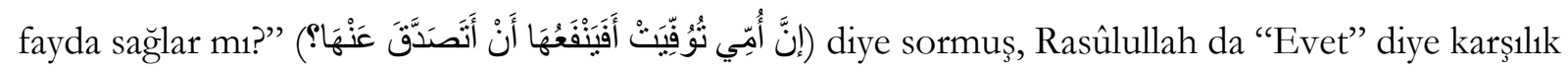
vermiştir. Bu konu kapsamında daha birçok hadis/haber nakledilebilir.

41 İbn Teymiyye, Mecmûu'l-Fetâvâ, 24: 366-367. 
Diğer taraftan, müctehid imamlar sadakanın ölüye fayda vereceğini kabul etmişler ve köle azat etmek gibi mali ibadetler konusunda da aynı görüşü benimsemişlerdir. Namaz, oruç ve Kur’an tilaveti gibi bedenî ibadetler hususunda ise ihtilaf etmişlerdir. Bununla birlikte, Buhârî (ö. 256/870) ve Müslim'in (ö. 261/875) naklettikleri bir hadiste, ölen kişi adına velisinin oruç tutabileceği bildirilmiştir. İbn Abbâs'tan gelen bir haberde ise bir kadın annesinin oruç borcu bulunduğu ve onun namına bu orucu tutup tutamayacağı hakkında sormuş, Rasûlullah da "Annenin mali borcu olsa o borcu ödemek zorunda olduğun gibi onun tutamadığı orucu da tutarsın” buyurmuştur. Bu haberler ve hadislerde anlatılan husus Necm 53/39. ayet ile "Âdemoğlu ölünce üç ameli hariç tüm amelleri kesilir" mealindeki hadisi olumsuzlamaz. Bütün bunların dışında Kur'an meleklerin müminler için istiğfarda bulunduklarını, onların cehennem ateşinden muhafaza edilip cennete girmeleri için dua ettiklerini bildirir. Bu istiğfar ve dua kula ait bir amel değildir. Yine Kur’an’da Hz. İbrahim’in, “

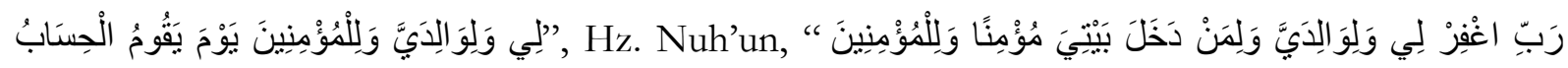
" dوَالْمُوِْْنَاتِ

İbn Teymiyye'nin meşhur talebesi İbn Kayyim el-Cevziyye, "Hayattaki insanların ibadet mahiyetindeki amellerinden ölülerin ruhları istifade eder mi etmez mi?” şeklindeki soruya dair şunları kaydetmiştir: Ehl-i Sünnet’in fikıh, hadis ve tefsir âlimlerinin icmaına göre hayattaki insanların amellerinden ölülerin ruhları faydalanır; fakat bu husus iki şarta bağlıdır: (1) Ölen kişinin hayatta iken söz konusu amele vesile olmasi; (2) Müslüman topluluğun ölüye dua etmesi, Allah’tan onun için af/mağfiret talebinde bulunması... Ölünün namına sadaka vermek, haccetmek gibi ibadetlerden hâsıl olan sevabın yerini bulup bulmayacağı meselesi ise tartışmalıdır. Cumhur ulemaya göre bu amellerin sevabı ölüye ulaşır. Oruç, namaz, Kur'an tilaveti gibi bedenî ameller konusu da tartışmalıdır. Selef ulemasının çoğunluğu ve Ahmed İbn Hanbel'e (ö. 241/855) göre bu tür amellerin sevabı ölüye ulaşır. İmam Ebû Hanîfe'nin (ö. 150/767) ashab1 (taraftarları) da bu görüştedir. Ebû Ca’fer Muhammed b. Yahyâ el-Kehhâl'den gelen rivayete göre bir kişi İbn Hanbel'e gelmiş ve namaz, sadaka gibi hayırlı ameller işlediğini ve bu amellerinin yarısını (vefat etmiş) babasına veya annesine bağışladığını söylemiştir. Bunun üzerine İbn Hanbel, "Bu amellerin yerine ulaşacağını ümit ediyorum" veya "Sadaka ve diğer bütün amellerin sevabı ölüye ulaşır" demiş, ayrıca söz konusu kişiye üç kez Âyetü'l-Kürsî ve İhlâs suresini okumasını tavsiye etmiştir... İbn Kayyim bu bilgileri aktardıktan sonra ‘'Imam eş-Şâfiî ve İmam Mâlik’ten gelen meşhur kavillere göre hayattaki insanların işledikleri

42 İbn Teymiyye, Mecmûu'l-Fetâvâ, 24: 306-311. 
salih amellerin sevabı ölüye ulaşmaz" şeklinde bir kayıt düşmüş, ardından da "Bidat ehli bazı kelamcılar dua ya da başka bir amelin ölülere ulaşmayacağı iddiasında bulundu" demiştir. ${ }^{43}$

\section{Değerlendirme}

Kur'an okumak bizatihi ibadettir. Kur'an'da "rabbenâ", "rabbi” diye başlayan birçok ayetin dua ayeti olduğu iyi bilinmektedir. Namaz ibadetinin olmazsa olmazı olarak kabul edilen Fâtiha suresinin 5-7. ayetleri de dua mahiyetindedir. Aynı şekilde genel olarak namazın, özel olarak cenaze

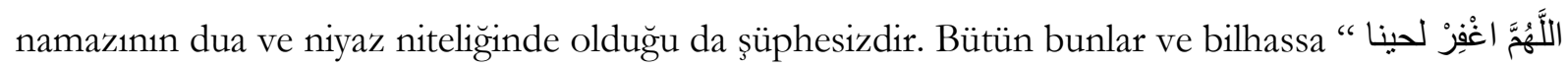

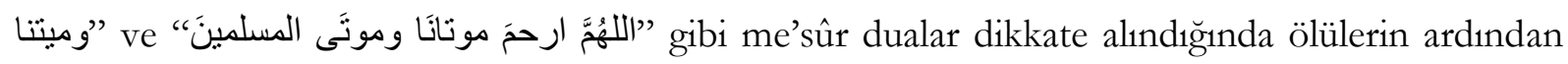
af/mağfiret istirhamı babında dua ve niyazda bulunmanın meşru olduğunu rahatlıkla söylemek mümkündür. Ancak Kur’an okuyup sevabını ölülere bağışlama ve bu sevabın ölülere ulaşıp ulaşmadığ1 konusunda Kur'an’dan sarih bir delil bulmak pek mümkün değildir.

Ölülerin ardından Kur’an okunabileceği görüşünü benimseyen âlimler bu görüşü kıyasa dayandırmış görünmektedir. Bu kıyasın dayanak noktası (makîsun aleyh) niyabeten sadaka, oruç ve hac gibi ibadetlerdir. Nitekim bir hadiste, Hz. Peygamber, Sa'd b. Ubâde’ye, vefat eden annesi adına sadaka vermesinin annesine fayda vereceğini söylediği bildirilir. ${ }^{44}$ Başka bir hadiste ise bir kişinin vasiyet bırakmadan ölen annesi adına vereceği sadakanın sevabından annesinin faydalanıp faydalanmayacağını sorması üzerine Hz. Peygamber'in, "Evet, faydalanır” diye cevap verdiği belirtilir. ${ }^{45}$

Burada tartışma konusu olan mesele ölülere sevap bağışlama maksadıyla Kur’an okumanın caiz veya meşru olup olmamasıyla ilgilidir. Bu konuda hadis olarak nakledilen bazı rivayetler İbn Ömer gibi kimi sahâbîlerin bunu meşru saydıkları, hatta kendi cenazelerinde bazı ayetler ve surelerin okunması vasiyetinde bulundukları belirtilmiş; fakat bu rivayetlerin büyük çoğunluğu hadis usulü açısından problemli olarak değerlendirilmiştir. ${ }^{46} \mathrm{~Hz}$. Peygamber ve sahabe devri dikkate alındığında ölülerin ruhlarına sevap bağışlama maksadıyla Kur’an okumak gibi bir geleneğin mevcudiyetinden söz etmek pek mümkün görünmemektedir.

Konuyla ilgili bir makaledeki değerlendirme de aynı istikamettedir. Buna göre ölülere Kur’an okunmasıyla ilgili Kur'an-1 Kerim'de ne doğrudan ne de dolaylı bir bilgi mevcuttur. Peygamberimi-

43 Ebû Abdillah Şemsüddîn Muhammed b. Ebî Bekr İbn Kayyim el-Cevziyye, er-Rûh, (Beyrut: Dâru'l-Kütübi'l-İlmiyye, ts.), 117.

44 Buhârî, "Vasâyâ", 15.

45 Buhârî, "Cenâiz", 93; Müslim, "Zekât”, 51.51.

46 Mustafa Özel, “Ölünün Ardından Kur'an-1 Kerim Okunmasının Dinî Dayanakları”, İslam Hukuku Araştırmalar Dergisi 7 (2006), 480-482. 
zin sözlerini içeren makbul ve muteber hadis kitaplarında da bu konuyu doğrudan ele alan sahih/sağlam bir haber bulunmamaktadır. Kaynaklarda yer alan hadislerin tamamına yakını ya zayıf ya da mevzu/uydurmadır. İslam'ın ilk dönemlerinde mevcut olmayan bu uygulama, büyük ölçüde, tarihî süreç içerisinde ortaya çıkan uygulamalara dayanmaktadır. Kur'an okumak bir ibadet olduğuna göre bunun insanın kendisi tarafindan gerçekleştirilmesi gerekir. Kur’an-1 Kerim’i yüzünden veya ezbere okumayı bilenler, ölen yakınları için bildikleri kadarını okuyabilirler. Ölünün ardından mevlid okunması yerine Kur'an okuma, ölü adına gerekli yerlere yardım yapma gibi ibadetlerin tercih edilmesi, bize daha uygun gözükmektedir” şeklinde değerlendirmeler yer almaktadır. ${ }^{47}$

Ne var ki dua içerikli birçok ayet ölülerin af ve mağfireti için de Kur'an okunabileceğini göstermektedir. Mesela, İbrahim 14/41. ayette mealen, "Rabbimiz! Hesap gününde beni, anamı, babamı ve bütün müminleri affeyle!" denilmektedir. Bu ayeti okuduğumuzda hem kendimiz hem ebeveynimiz hem de tüm mümin kardeşlerimiz için kıyamet ve hesap gününde Allah’tan af ve mağfiret talebinde bulunmuş olmaktayız. Allah'tan af ve mağfiret talebinde bulunduğumuz anne-babamız ve mümin kardeşlerimizin hayatta olmaları gibi bir zorunluluk yoktur. Dolayısıyla ahirete irtihal etmiş olan ve her birimiz gibi ilâhî rahmete muhtaç halde bulunan ebeveynimiz ve mümin kardeşlerimiz için bu ayeti okuduğumuzda hem Kur'an okumuş hem de onların affi için dua ve niyazda bulunmuş olduğumuz kuşkusuzdur.

Bu noktada iki kritik konu vardır. Birincisi, özellikle İbrahim 14/41. ayet dikkate alındığında dua niyetiyle Kur'an okuyan kimsenin "Kişi öldügünde üç ameli hariç diğer bütün amelleri kesilir. Sadaka-i câriye, faydalı ilim ve kendisine dua edecek hayırlı evlat" hadisinde ${ }^{48}$ işaret edilen "hayırlı evlad"a karşılık gelmesidir. İkinci kritik konu ise Kur'an okuyup ölülerin ruhlarına bağışlamanın dinî alanda istismar sektörü hâline gelmemesi, getirilmemesidir. Fakat ne yazık ki ülkemizde bu alanda çok etkin bir sektör mevcuttur. Bir yaklaşıma göre bu konuda şunu söylemek de mümkündür: “Ticari amaç gütmeksizin sırf Allah için okunup ölüye bağışlanan Kur’an'dan dua mahiyetinde ölünün bundan istifade edeceği kanaatindeyiz. Nevevî’nin de belirttiği gibi bu konuda zikredilen zayıf rivayetlerle amel edilebilir. Ancak buna sünnet gözüyle bakmanın uygun olmayacağı kanaatindeyiz." 49

Öte yandan, Nevevî kendi mezhebinin görüşünü akartma babında "Ashabımız şöyle dedi”" ifadesinden sonra, "Mezarllğı ziyaret eden kişinin öncelikle kabirdekilere selam vermesi, daha sonra

47 Özel, “Ölünün Ardından Kur'an-1 Kerim Okunmasının Dinî Dayanakları”, 484-486.

48 Müslim, "Vasiyyet", 14; Ebû Dâvûd, "Vasâya", 14; Nesâî, "Vasâyâ", 8.

49 Kâmil Çakın, Hadis inkârcıları, (Ankara: Seba Yayınları, 1998), 70-71. 
hem ziyaret ettiği kimselere hem de kabristandaki diğer bütün ölülere dua etmesi ve Kur'an'dan kolayına gelen ayetler/sureleri okuduktan sonra ölülere dua ve niyazda bulunması müstehaptır" demiş, ardından da bu görüşün bizzat İmam eş-Şâfî̀ye ve Şâfî̀ ulemasına ait olduğunu açıkça belirtmiştir. ${ }^{50}$ Bazı araştırmacıların tespitlerine göre hicrî 6. asırdan itibaren İzzeddin b. Abdisselâm hariç, Şâfî̂ âlimleri ölülere Kur'an okunabileceği yönündeki görüşü benimsemişlerdir. Başta İmam el-Gazâlî (ö. 505/111) olmak üzere İbnü’s-Salâh eş-Şehrezûrî (ö. 643/1245), Ebû Zekeriyy1 enNevevî, Muhibbüddîn et-Taberî (ö. 694/1295), Suyûtî, Hatîb eş-Şirbînî (ö. 977/1570) gibi birçok Şâfî̂ âlim ölülere Kur'an okunacağı görüşünde birleşmişlerdir. ${ }^{51}$

Öte yandan, son dönem Hanefî fakihlerinden İbn Âbidîn Şifâu'l-Alîl ve Bellül-ĞGalîl adlı risalesinde Hanefî ekolünün görüşünü ortaya koyduktan sonra Kur'an okumanın bir ibadet olduğunu ve ibadet maksadıyla yapılan her amelin sevabının ölülere bağışlanabileceğini belirtmiş; fakat günümüzde de sık rastlanan şu yanlışa dikkat çekmeyi de ihmal etmemiştir: "Ölüye fayda vermesi için ücret mukabilinde Kur'an okutmak batıldır. Ölümünden sonra kendisine Kur'an okunmasını vasiyet eden kişi de aynı hüküm kapsamındadır. Çünkü böyle bir vasiyet, ücretle Kur'an okutmaktan farksızdır... Kur'an okumak bizatihi ibadettir. Bir amelin kendisinden sevap umulan bir ibadet olabilmesi için gösterişten uzak şekilde sırf Allah rızasına yönelik olması gerekir. Ücret mukabilinde Kur'an okuyan kimse, sevap yerine maddi çıkar beklentisi içindedir. Bu itibarla, ücretle okunan Kur'an'dan sevap hasıl olmaz, dolayisıyla ölüye de faydası dokunmaz." 52

\section{SONUÇ}

Sonuç olarak, başta Haşr 59/10 ve İbrahim 14/41. ayetler olmak üzere Kur'an'daki birçok ayette Müslümanların hem kendileri hem anne-babaları hem müminler ve hem de kendilerinden önce gelip geçen din kardeşleri için Allah'a yakardıkları, hatta bu minvalde dua ve niyazda bulunmaları gerektiği bildirilir. Özellikle İbrahim 14/41. ayetteki, "Rabbimiz, beni, ana-babamı kıyamet

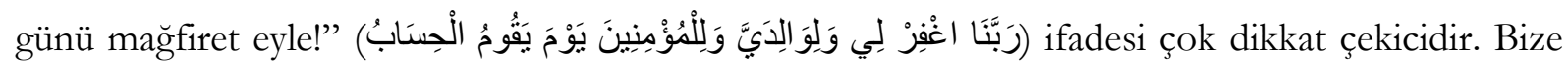
göre bu ayet Allah'tan af/mağfiret talebiyle Kur'an okunmasının meşruiyetine dair en güçlü delillerden biridir. Kur'an okumak suretiyle Allah'tan talep edilen af ve mağfiretin O'nun katında karşıllk bulup bulmayacağı hiç şüphesiz biz kulların bilebileceği bir şey değildir. Konunun bu yönü tamamen ilahi iradeyle ilgilidir.

50 Ebû Zekeriyyâ Muhyiddîn Yahyâ b. Şeref en-Nevevî, el-Mecmû' Şerbü'l-Mühezzz̨eb, (Beyrut: Dâru'l-Fikr, ts.), 5: 311.

51 Acar, Rivayet Ilimleri Açısından Hayattakilerin Yaptĭg İbadet ve Kıraatten Ölülerin Faydalanması Meselesi, 205-206.

52 Muhammed Emîn b. Ömer İbn Âbidîn, Şifâu'l-Alîl ve Bellü'l-Ğal̂̀l, [Mecmûatü Resâili İbn Âbidîn içinde], (Beyrut: Âlemü'l-Kütüb, ts.), 167-168. 
Kur'an tilavetinin sevap olarak ölüye ulaşacağ1 yönündeki görüş en nihayet engin ilâhî rahmet ve mağfirete ilişkin bir ümit ve beklentiye dayanır. En başta besmele ifadesiyle kendini sınırsız rah-

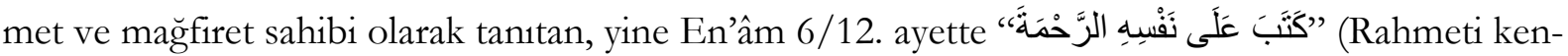

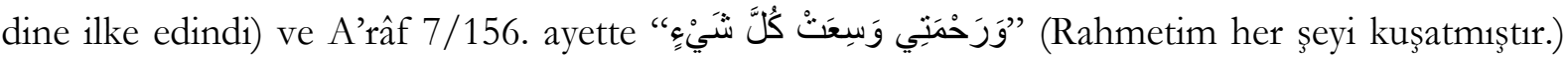
buyuran Allah mümin kullarına hitaben dualara icabet edeceğini de bildirdiğine göre O'na yönelik en güzel dua ve niyazlarda yine O'nun kelamının vesile kılınması kuşkusuz daha uygundur. Bize kendi kelamında nasıl dua edeceğimizi öğreten Allah'ın bu dua ayetlerini okuduğumuz zaman O’nun nezdinde karşılık bulacağı umulur. Mamafih, çoğunluk İslam ulemasının ölülere Kur'an okunabileceği yönündeki görüşünü günümüzde sektör hâline dönüşmüş olan hatim ve mevlid gibi uygulamalarla irtibatlandırmamak gerekir. Zira günümüzdeki bu uygulamalar, tabir caizse, şirazesinden çıktığı için, Kur'an çoğu zaman hastalara şifa, ölülere sevap niyetiyle okunan bir kutsal metin olarak algılanır hâle gelmiştir. Bize göre bu algının bilgisizlik, iyi niyet ve samimiyet gibi faktörlere rağmen çok açık bir inhiraf olduğu izahtan varestedir.

Konuyla ilgili rivayetlerden anlaşıldığ1 kadarıyla, ölülere Kur’an okuyup sevap bağışlamak gibi bir uygulama Hz. Peygamber döneminde mevcut değildir. Dolayısıyla bu konuda nebevi bir sünnetten söz etmek pek mümkün görünmemektedir. Kabristan ziyareti ve ölülere Kur’an okuma hususunda bazı sahâbilerden merfu ve/veya mevkuf olarak nakledilen haberler ve hadislerin hemen tamamı senet (sübut) yönünden problemlidir. Bununla birlikte İbn Ömer ve Leclâc gibi sahâbîlerin öldükten sonra kendileri için Kur’an okunması yönündeki vasiyetleri ile Şa’bî’nin “Ensar ölülerinin yanında Bakara suresini okurlardı" şeklindeki ifadesi ölülere Kur'an okuma âdetinin nebevi sünnet olmamakla birlikte sahabe arasında ortaya çıkmış bir uygulama olduğuna karine sayılabilir. Öte yandan, cenaze namazında Fâtiha suresini okumanın Şâfî̀ ve Hanbelî mezheplerinde bir rükün olarak kabul edildiği bilinmektedir. Cenaze namazı ölüye dua mesabesindedir. Dolayısıyla bu namazda Fatiha okumak ölüye dua ve istiğfar maksadıyla Kur'an okumak anlamına gelir. 


\section{KAYNAKÇA}

Acar, Yusuf. Rivayet İlimleri Açısından Hayattakilerin Yaptı̆ğ İbadet ve Kıraatten Ölülerin Faydalanması Meselesi. İstanbul: A.H.İ. Yayıncılık, 2004.

Ali el-Kârî, Ebü'l-Hasen Nûrüddîn Ali b. Sultân. Mirkâtuï'l-Mefâtîh. Beyrut: Dâru'l-Fikr, 2002.

Aynî, Ebû Muhammed Bedrüddîn Mahmûd. el-Binâye fî Şerbi'l-Hidâye. Beyrut: Dâru'l-Kütübi'l-ìlmiyye, 2000.

Beyhakî, Ebû Bekr Ahmed b. Hüseyn. Şuabü'l-Îmân. nşr. Muhammed Saîd Besyûnî Zağlûl, Beyrut: Dâru'l-Kütübi'l-İlmiyye, 2000.

Beyhakî, Ebû Bekr Aḥmed b. el-Hüseyn. Şuabü’l-Îmân. nşr. Abdülalî Abdülhamîd, Riyad: Mektebetü'r-Rüşd, 2003.

Buhârî, Ebû Abdillah Muhammed b. İsmail. el-Câmin's-Sahîh. İstanbul: Çağrı Yayınları, 1981.

Cessâs, Ebû Bekr Ahmed b. Ali. Abkâmu'l-Kur'ân. nşr. Muhammed Sâdık Kamhâvî, Beyrut: Dâru İhyâi't-Türâsi'l-Arabî, 1412/1992.

Çakın, Kâmil. Hadis inkâraları. Ankara: Seba Yayınları, 1998.

Ebû Dâvûd, Süleyman b. Eş’as es-Sicistânî. es-Sünen. İstanbul: Çağrı Yayınları, 1981.

Elbânî, Muhammed Nâsıruddîn. Ahkâmu'l-Cenâir: Beyrut: el-Mektebetü'l-İslâmiyye, 1969.

Ersoy, Mehmet Akif. Safahat. der. Ömer Rıza Doğrul, İstanbul: İnkılap ve Aka Kitabevi, 1979.

Fevzân, Sâlih b. Fevzân b. Abdillah. el-Bid'a Ta'rifuhâ Envâuhâ ve Abkâmubâ. Riyad: el-Mektebetü’tTeâvünî li'd-Da've ve'l-İrşâd, 1422.

Hâkim en-Nîsâbûrî, Ebû Abdillah Muhammed b. Abdillah. el-Müstedrek ale's-Sabîhayn. nşr. Mustafa Abdülkâdir Atâ, Beyrut: Dâru'l-Kütübi'l-İlmiyye, 1995.

Hallâl, Ebû Bekr Ahmed b. Muhammed. el-Kırâe inde'l-Kubûr. nşr. Yahya Murad, Beyrut: Dâru'lKütübi’l-İlmiyye, 2003.

Heysemî, Ebü’l-Hasen Nûrüddîn Alî b. Ebî Bekr. Mecmen'そ̌-Zevâid ve Menbeu'l-Fevâid. nşr. Hüsâmüddîn el-Kudsî, Kahire: Mektebetü’l-Kudsî, 1994.

İbn Âbidîn, Muhammed Emîn b. Ömer. Şifâu'l-Alîl ve Bellï'l-Ğalîl. [Mecmûatü Resâili İbn Âbidîn içinde], Beyrut: Âlemü’l-Kütüb, ts.

İbn Âşûr, Muhammed Tâhir. Tefsîru't-Tahrîr ve’t-Tenvîr. Tunus: Dâru't-Tûnîsiyye, 1984.

İbn Battâl, Ebü'l-Hasen Ali b. Halef el-Kurtubî. Şerbü Sabîhi'l-Bubârî. nşr. Ebû Temîm Yâsir b. İbrâhîm, Riyad: Mektebetü’r-Rüşd, 2003.

İbn Hacer el-Askalânî, Ebü'l-Fazl Şihâbüddîn Ahmed b. Ali. el-İmtâ' bi'l-Erbaîne'l-Mütebayineti’s-Semâ. nşr. Ebû Abdillah Muhammed Hasen, Beyrut: Dâru’l-Kütübi’l-İlmiyye, 1997. 
İbn Hacer el-Askalânî, Ebü'l-Fazl Şihâbüddîn Ahmed b. Ali. Telhîsü'l-Habîr. Beyrut: Dâru'l-Kütübi'l-İlmiyye, 1989.

İbn Hibbân, Ebû Hâtim Muhammed b. Hibbân el-Büstî. es-Sahîh. nşr. Şuayb el-Arnaût, Beyrut: Müesssesetü’r-Risâle, 1988.

İbn Kayyim el-Cevziyye, Ebû Abdillah Şemsüddîn Muhammed b. Ebî Bekr. er-Rûh. Beyrut: Dâru’lKütübi'l-İlmiyye, ts.

İbn Kudâme, Ebû Muhammed Muvaffakuddîn Abdullah b. Ahmed. el-Muğnî. nşr. Abdullah b. Abdilmuhsin et-Türkî-Abdülfettâh Muhammed el-Hulv, Riyad: Dâru Âlemi'l-Kütüb, 1997.

İbn Mâce, Ebû Abdillah Muhammed b. Yezîd. es-Sünen. nşr. M. Fuad Abdülbâkî, İstanbul: Çağr1 Yayınları, 1981.

İbn Teymiyye, Ebü'l-Abbâs Takıyüddîn Ahmed b. Abdilhalîm. el-Fetâva'l-Kübrâ. Beyrut: Dâru’lKütübi'l-İlmiyye, 1987.

İbn Teymiyye, Ebü'l-Abbâs Takıyyüddîn Ahmed b. Abdilhalîm. Mecmûu'l-Fetâvâ. nşr. Abdurrahmân b. Muhammed b. Kâsım, Medine: Mecmeu'l-Melik Fehd, 1995.

Kurtubî, Ebû Abdillah Muhammed b. Ahmed. el-Câmi' li Abkâmi'l-Kur'ân. nşr. Ahmed Berdûnîİbrahim Itfeyyiş, Kahire: Dâru'l-Kütübi'l-Kütübi'l-Mısriyye, 1964.

Kurtubî, Ebû Abdillah Muhammed b. Ahmed. et-Tezkira bi Abvâli'l-Mevtâ ve Umûri'l-Âhira. Riyad: Mektebetu Dâri'l-Minhâc, 1425/2004.

Mâverdî, Ebü’l-Hasen Ali b. Muhammed. el-Hâvi'l-Kebîr. nşr. Ali Muhammed Muavvız-Âdil Ahmed Abdülmevcûd, Beyrut: Dâru'l-Kütübi'l-İlmiyye, 1999.

Müslim, Ebü'l-Hüseyn Müslim b. el-Haccâc. el-Câmiu's-Sahîh. nşr. M. Fuad Abdülbâkî, İstanbul: Çağrı Yayınları, 1981.

Nesâî, Ebû Abdirrahmân Ahmed b. Şuayb. es-Sünen. İstanbul: Çağrı Yayınları, 1981.

Nevevî, Ebû Zekeriyyâ Muhyiddîn Yahyâ b. Şeref. Sabîhu Müslim bi-Şerbin'n-Nevevî (el-Minhac fi şerbi Sabîhi Müslim b. Haccâc). Beyrut: Dâru İhyâi't-Türâsi'l-Arabî, 1392/1972.

Nevevî, Ebû Zekeriyyâ Muhyiddîn Yahyâ b. Şeref. el-Eæ̌kâr. nşr. Abdülkâdir el-Arnaût, Beyrut: Dâru'l-Fikr, 1994.

Nevevî, Ebû Zekeriyyâ Muhyiddîn Yahyâ b. Şeref. el-Mecmû' Şerbü'l-Mühezzzeb. Beyrut: Dâru'l-Fikr, ts.

Özel, Mustafa. “Ölünün Ardından Kur’an-1 Kerim Okunmasının Dinî Dayanakları”. İslam Hukuku Arasturmalar Dergisi 7 (2006).

Öztürk, Mustafa. “İslâmî Kökenciliğin Bir Tezahürü: Mealcilik”. İslâmiyât 10/1 (2007).

Öztürk, Mustafa. Çăgdaş İslam Düşüncesinde ve Kur'ancılk. Ankara: Ankara Okulu Yayınları, 2013. 
Suyûtî, Ebü'l-Fazl Celâlüddîn Abdurrahmân b. Ebî Bekr. el-İtkân fî Ulùmi'l-Kur'ân. nşr. Muhammed Ebü’l-Fazl İbrahim, Kahire: el-Hey'etü'l-Mısriyyetü'l-Âmme li’l-Küttâb, 1974.

Suyûtî, Ebü’l-Fazl Celâlüddîn Abdurrahmân b. Ebî Bekr. Şerbü's-Sudûr bi-Şerhi H Hâli'l-Mevtâ ve'lKubûr. nşr. Abdülmecîd Ṭu'me Halebî, Beyrut: Dâru'l-Ma'rife, 1996.

Şevkânî, Ebû Abdillah Muhammed b. Ali. Neylü'l-Evtâr. Riyad: Dâru İbni'l-Cevzî, 1427.

Taberânî, Ebü'l-Kâsım Süleymân b. Ahmed. el-Mu'cemü'l-Kebîr. nşr. Hamdî Abdülmecîd es-Silefî, Kahire: Mektebetü İbn Teymiyye, ts.

Taberî, Ebû Ca'fer Muhammed b. Cerîr. Câmiu'l-Beyân fî̀ Te'vîli Âyi'l-Kur'ân. nşr. Ahmed Muhammed Şâkir, Beyrut: Müessesetü’r-Risâle, 2000.

Tayâlisî, Ebû Dâvûd Süleymân b. Dâvûd. el-Müsned. nşr. Muhammed b. Abdilmuhsin et-Türkî, Kahire: Dâru Hecr, 1999.

Tirmizî, Ebû İsa Muhammed b. İsa. es-Sünen. İstanbul: Çağrı Yayınları, 1981.

Yelken, Ramazan. “İnananlar İçin Hâlâ Vakit Gelmedi mi?”. Kalem Dergisi 1 (Ocak-1988).

Yıldırım, Ali. Din Dilinin Anlamı: Doğrulamacı ve Isslevselci Yaklaşımlar. Yayımlanmamış Doktora Tezi, Marmara Üniversitesi, 2012. 